\title{
Social Marketing: A Classic Case of Sustainability Model by Hindustan Unilever Ltd.
}

\begin{abstract}
Growing consumer and increasing income growing of consumer opens many avenues for modern marketers to serve consumers. Market and society are the two sides of a single coin. To develop the society, marketers have a greater role of sustainability. While manufacturing new product for the consumer group, companies should take every precaution and necessary steps to protect the interest of the consumers as well as safeguard the consumer's priorities. A better and sustainable earth is also the concern for Govt. as well as many companies of the globe, who are using resources of earth like water, minerals, trees etc for further processing of their products. This paper focus on several steps initiated by HUL for their forthcoming as well as current products, where company plans to launch many eco-friendly products which save mother earth as well as protect consumer from any hazards.
\end{abstract}

Keywords: Sustainability, HUL, Consumer, Market. Social Marketing

\section{Introduction:}

AMA defined Marketing as "Transfer of goods and services from producers/manufacturer to ultimate consumers." Social Marketing is the integration of Marketing Philosophy with changing nature of society. Today consumer needs more comfort, quick solution for his problems, frequent change of his needs and comfortable zone of shopping. This un-certainty ponders marketers to design their marketing planning in a more systematic ways. The modified version of recently AMA definition on marketing somehow indicates towards the above issues.

The revised definition of marketing as AMA stated is:

Marketing is

\begin{tabular}{|ll|}
\hline$\rightarrow$ & Creating (New Products Development.) \\
\hline$\rightarrow$ & Communicating (Promotional Mix) \\
\hline & Supplying (SCM) \\
\hline$\rightarrow$ & Maintaining CRM with Consumers
\end{tabular}

In this process maintaining relationship with consumer play a pivotal role where company keeps every social change in the society into consideration while initiating any new plan of marketing.

\section{HUL, A Milestone in FMCG Industry:}

The $\in 46$ billion FMCG giant HUL was formed in 1933 as Lever Brothers India Ltd. and came into being in 1956 as Hindustan Lever Ltd. through a merger of Lever brothers, Hindustan Vanaspati Mfg.co. Ltd. and United Traders Ltd. HUL distribute its products through 2 million retail outlets across the country directly and products are available in over 7.2 million outlets in the country. As per AC Nielsen market research data, two out of three Indians use HUL products. HUL is the market leader in Indian consumer products with presence in over 20 consumer categories such as soaps, tea, detergents and shampoos.

\section{Unilever Sustainable Living Plan (USPL) :}

Unilever launched sustainable living plan in on $15^{\text {th }}$ of November, 2010 at London, Rotterdam, New York and New Delhi simultaneously. Under this plan, Unilever aims to achieve few goals by 2020. These goals are :

- Help more than one billion people to improve their health and well being.

- Environment impact of their products should reduce to half of current status.

- Outsource $100 \%$ of their agricultural raw materials sustainability.

\section{Current Progress Report on Sustainability:}

Unilever is on track in sustainable sourcing and livelihoods, but unable to reduce the environmental impact. Company is currently focusing on seven major areas, where sustainability is required. These areas are :

$>$ Health and Hygiene

$>$ Nutrition

$>$ Waste foot print

$>$ Water foot print

$>$ Green house gases 
$>$ Sustainable sourcing

$>$ Better livelihoods

\section{Health and Hygiene :}

According to UN estimates, over 2 billion people have limited access to safe drinking water. Many Unilever brands offer hygiene benefits. Lifebuoy is one among them. By 2015, this brand aims to change the hygiene behaviour of 1 billion consumers across Asia, Africa and Latin America by promoting the benefits of hand washing at key times. In India, HUL has garnered immense learning from its years of experience in conducting the Lifebuoy hand washing programme. The Madhya Pradesh Govt., impressed by the fact that the incidence of diarrhea has dipped by $25 \%$ in a recent study. In Pakistan, Lifebuoy soap consumption has increased by $8 \%$. HUL's major toothpastes also play an important role helping to prevent tooth decay which is one of the world's most common diseases and can lead to more serious health conditions. The simple practice of brushing twice a day can make a big difference to oral health.

Also Pureit, company's in-home water purifier, provide water 'as safe as boiled' without needing electricity and at an affordable price to India's middle class consumers. "Khushiyon ka Doli" (Caravan of Happiness) is company's Lifebuoy brand promotional activities in rural India where it is reaching to 30 million rural consumers directly.

\section{Nutrition:}

High level of obesity is now a concern for urban India where consumers are living more sedentary lives and calorie rich foods are more available and affordable. Millions of the people around the globe remain hungry or lack of essential nutrients in their diets. HUL, in its "Nutrition enhancement Programme" plans to improve the nutritional quality. By 2020, company is planning to motivate around 100 million people to take its "Heart Age' test for better and healthier lifestyle. Unilever has been gradually reducing salt levels in its products without changing its taste, as it is framed under the goal of company. The aim is to reduce the level of salt up to the mark of $5 \mathrm{gm}$ per day as based on globally dietary guidelines. Under food programme, company providing micronutrient - enriched school meals to 95,000 school children of India, Bangladesh and Indonesia. Company also committed to reduce saturated facts, Trans fat and calories from their different products to uplift consumers' healthy eating habits.

\section{Waste Foot Print:}

Packaging is one of the important Ps defined by Marketing Scientists. It protects the products and allows company to transport them safely from manufacturing base to consumer end. At the same time it can end up as waste, particularly in those countries where the infrastructure for recycling is poor. So company is reducing the packaging and saving the materials, energy and transport. By 2020, company will reduce the weight of packaging that what currently it is using by a third through light weighting materials. Company is planning to provide consumers with refills for their home and personal care products to make it possible to reuse the primary pack.

Sachets and pouches are an efficient use of packaging creating less waste by weight per milliliter of product sold than bottles. Sachets play an important role in making everyday product affordable and accessible to low income consumers. But recycling sachets really a challenging issue due to its low weight. But Unilever introduce a technology called "Breakthrough Pyrolysis Process", where used plastic sachets can be converted to fuel. Company also eliminating PVC (Polyvinyl Chloride) from all its packaging by 2012. As company is the firm believer of sustainability, hence it has joined hands with Bharti Retail to implement a programme called 'go recycle', where consumers are educated and informed about the practice of waste segregation. As a part or this programme, consumers were encouraged to bring empty plastic bottles and pouches of any brand from selected FMCG categories. In return, the consumers were given discounts coupons for redemption.

\section{Water foot print:}

Water is a basic human need. The United Nations estimates that each person needs 20-50 liters per day for drinking and daily tasks like cooking and washing. Water shortages are increasingly common and water available per head or population will reduce further in the coming decade, as predicated by UN. Company is committing to halve the water associated with the consumer use of its products by 2020. For Ex: Company is planning to launch a dry shampoo that does not need water in a far easier way to reducing water consumption in the bathroom than pleading with them to use less water. The dry shampoo is spray on, absorbs oil from hair and also lends volume. Company already introduced comfort one Ringe in Vietnam that reduces the use of water from their buckets to one. Also introduces a leave on hair conditioner that doesn't need to be washed away. Also a detergent that clean at room temperatures, doing away with the need for hot water at $70^{\circ}$ Celsius in washing machines. 


\section{Greenhouse Gases:}

By 2020 company is committing to halve the greenhouse gas impact of its products. Climate change will have a growing impact on Unilever's business. Changing weather patterns put the suppliers of agriculture raw materials in mess. So company is planning to set greenhouse gas reduction targets across the valve chainfrom sourcing, manufacturing, transport and refrigeration all the way through to consumer use of the products. Most of the greenhouse gas emissions are come from the hot water needed to use company's soaps and shampoos in the shower. So company is persuading consumers to take shorter showers. By $2020, \mathrm{Co}_{2}$ emissions from global logistics network will be below the level of target set for 2010. Truck transportation may replace with rail or ship to reduce $\mathrm{Co}_{2}$. Also it plans to improve the Energy efficiency of its warehouses.

\section{Sustainable Sources:}

Half of Unilever's raw materials come from either farms or forests. Agriculture and forestry are the largest contributors to global greenhouse gas emissions and are the major drivers of climate change. So Unilever is committed to sourcing sustainably all agricultural raw materials by 2020. By 2015, company will purchase all palm oil from certified sustainable sourcing, for soy beans target set is 2014 and for soy oil by 2020 .

Unilever's master brand Lipton tea bags will source from Rainforest Alliance certified estates by 2015 . Company will purchase $100 \%$. Sustainable fruits and vegetables by 2015. Sustainable sunflower oil, Rapeseed oil and diary will be sourced by the company by 2020 .

\section{Better Livelihood:}

Company plans to help small holder farmers and Micro-entrepreneurs under project Shakti. It will increase the numbers or Shakti Ammas from 45,000 to 75,000 in 2015. To strengthen the project, Company introduced the concept of "Shaktimaan" under which men of Shakti families are given bicycle to cover surrounding villages to increase HUL's distribution and sales as well as enhance the income of Shakti families. Currently 30,000 Shaktimaans are working across India. HUL is also partnering with a leading public sector bank in India for enabling banking service to rural consumers and low income people is Shakti villages. HUL is also entered into a partnership on telecom distribution with a leading telecom company to sell its products and servicing across rural India. This initiative will help Shakti entrepreneurs to increase their income by selling telecom products and services to retailers, as well as directly to consumers.

\section{Conclusion :}

Unilever, as in the USLP, has put out a list of clean wants- all focused on sustainability- like fighting viruses, reduction of salt in food products, preserving food naturally, storing renewable energy, sustainable showering, and finally twisting the consumer behavior through its nobly created sustainable models. These factors are also helping company to increase its goodwill and support the sales volume target. Any social initiatives must be verified and weighted according to the consumer's perception and Unilever perfectly did the same by keeping its ideas fit to the shoes of consumer's mentality.

\section{Reference :}

www.unilever.com/sustainble-living

www.hul.co.in

$>$ www.wikipedia.com

$>$ HUL Bets on innovations to Reach Sustainable goal, The Economics Time, 25th April 2012 